\title{
A DESOBRIGA ESCRAVA OU O TEMPO QUE OS ESCRAVOS TINHAM PARA SI. UM ESTUDO SOBRE ECONOMIA INDEPENDENTE DOS CATIVOS NA SEGUNDA METADE DO SÉCULO XIX. ${ }^{1}$
}

The justification slave or slaves had time for you. A study on independent economy of captives in the second half of the 19th century.

http://dx.doi.org/10.21116/2019.1

\section{CERDAN, Marcelo Alves}

Centro Universitário Max Planck

RESUMO: O artigo busca analisar e fazer um balanço historiográfico de práticas produtivas independentes e atividades de lazer entre os escravos, a partir de análises de alguns estudos sobre a escravidão brasileira e de certas experiências de escravos que viveram em Itu entre 1850 e 1888.

Palavras-chave: História do Brasil. Escravidão. Desobriga escrava. Economia escrava. Lazer dos escravos. Itu/SP.

ABSTRACT: The article aims to analyze and to make a historiographic balance of independent productive practices and leisure activities among the slaves, based on analyzes of some studies on Brazilian slavery and certain experiences of slaves who lived in Itu between 1850 and 1888.

Keywords: History of Brazil. Slavery. Slave relieve. Slaves' economy. Slaves' leisure. Itu/SP.

\section{INTRODUÇÃO}

Num domingo da segunda metade do século XIX em Itu, depois de meses cultivando sua pequena roça, o escravo vestiu-se com sua melhor roupa e dirigiu-se ao centro da cidade para negociar o resultado da colheita em seu próprio lote de terra ou a galinha ou o porco que criara durante meses em seu quintal. Com o dinheiro da venda, ele poderia até comprar um agrado à família, certos gêneros alimentícios para suplementar suas refeições diárias ou poupálo para compra de futura alforria. Dali, poderia até ir à fonte da rua do Pirahy ou à Praça da Matriz para encontrar companheiros de outros plantéis ou, então, passar no botequim para beber cachaça ou jogar carteado. (CERDAN, 2013)

Outros escravos, talvez, poderiam não ter ido naquele dia à cidade por falta de tempo, pois suas roças requeriam suas constantes atenções. Quem sabe alguns deles preferissem mesmo embrenharem-se nas matas à caça de

${ }^{11} \mathrm{O}$ presente artigo é parte da tese "O tempo que o escravo tinha para si: um estudo sobre autonomia escrava em Itu de 1850 a 1888", defendida para obtenção do título de Doutor, em 2013, pela UNESP - Franca-SP. 
pequenos animais ou pescar. Também uma indisposição física, por ter dançado e batucado toda noite anterior, numa festa na senzala, pudesse ter impedido que alguns deles aproveitassem seu dia de desobriga na cidade. Alguns escravos, que residiam na zona urbana, em seus momentos de desobriga, poderiam prestar serviços extras, como lavar roupas, rachar lenhas, cortar capim e vender produtos pelas ruas ou encontrar com os colegas que residiam nos sítios e tinham vindo à cidade. (CRDAN, 2013)

As situações descritas acima, apesar de não se referirem a situações específicas, são inspiradas em experiências extraídas de fontes de informações relativas a Itu da segunda metade do século $\mathrm{XIX}^{2}$ e representam situações plausíveis aos milhares de escravos que participaram de sua história, e que poderiam, conforme sugerem diversos estudos e fontes, muito bem refletirem a realidade de escravos que viveram em outras regiões brasileiras daquele período. ${ }^{3}$

A "desobriga", o "tempo que tinham para si" ou "o tempo livre dos escravos" são expressões que designam um fenômeno que ocorreu em distintos

\footnotetext{
${ }^{2} \mathrm{~A}$ construção narrativa dos dois primeiros parágrafos tem como parâmetro evidências relativas a experiências de alguns escravos que viveram em Itu na segunda metade do século XIX, que foram retiradas das seguintes fontes de informações: Autos Crimes. Autora: a Justiça/Réu: Generoso, escravo da Baronesa de Itu. Pasta 79. 1861. Arquivo/Museu Republicano de Itu/USP; Autos Crimes. (Autora: a Justiça/Réu: Cesário e Antonio, escravos). Pasta 88. 1866. Arquivo/Museu Republicano de Itu/USP; Autos Crimes. Autora: a Justiça/Réu: Miguel, escravo da Herança de Felis Brasil. Pasta 82. 1863. Arquivo/Museu Republicano de Itu/USP; Sumario Culpa (Autor - A Justiça; Réu: Guilherme, escravo da Baronesa de Itu). Pasta 73, 1859: Museu Republicano - USP - Itu - SP; Processo Crime (Autor - A Justiça; Réu - Vicente, José e Athanasio). Pasta 79, 1862: Museu Republicano - USP - Itu - SP; Autos Crimes (Autor - A Justiça; Réu - Bernardo, escravo de Casimiro Mercadante. Pasta 79, 1862: Museu Republicano - USP - Itu - SP; Tribunal do Jury (Autor - A Justiça; Réu - Bernardo, escravo de Casimiro Mercadante. Pasta 116, 1879: Museu Republicano - USP - Itu - SP; Imprensa Ytuana, Ano I, ${ }^{\circ}$ 29, 03/09/1876, p. 04.

${ }^{3}$ Quanto à bibliografia referente ao aproveitamento do tempo que tinham para si para atividades produtivas ver: CARDOSO, Ciro Flamarion. Escravo ou camponês? O protocampesinato negro nas Américas. São Paulo: Brasiliense, 1987; GUIMARÃES, Elione Silva. Economia autônoma de escravos nas grandes fazendas cafeeiras do sudeste do Brasil (zona da Mata Mineira século XIX). América Latina em La História Econômica, $n^{\circ}$ 32, Jul/Dez de 2009; MACHADO, Maria Helena P. T. Crime e escravidão: trabalho, luta e resistência nas lavouras paulistas - 18301888. São Paulo: Editora Brasiliense, 1987; SCHWARTZ, Stuart. Escravos, roceiros e rebeldes. Bauru: EDUSC, 2001; SLENES, Robert W. Na Senzala uma flor. Esperanças e recordações na formação da família escrava. Rio de Janeiro: Nova Fronteira, 1999.

Em atividades lúdicas e sociais: QUINTÃO, Antonia Aparecida. Irmandades negras: outro espaço de luta e resistência (São Paulo: 1870-1890). São Paulo: Anablume/FAPESP, 2002; REIS, João José. Tambores e temores: a festa negra na Bahia na primeira metade do século XIX. In: CUNHA, Maria Clementina Pereira (org). Carnavais e outras Frestas. Ensaios de História Social da Cultura. Campinas: Editora da Unicamp, 2002; SOARES, Mariza de Carvalho. Devotos da cor: identidade étnica, religiosidade e escravidão no Rio de Janeiro do século XVIII. Rio de Janeiro: Civilização Brasileira, 2000.
} 
locais do continente americano durante o período escravista, desde os Estados Unidos da América, passando pela América Central e do Sul. No Brasil, há registros de sua existência e do seu aproveitamento para o cultivo de lotes de terras por cativos negros desde o século XVII, prática que, como observou Jacob Gorender, já se fazia na Ilha de São Tomé, desde antes da colonização do Brasil (GORENDER,1978, p. 258-259).

Ciro Flamarion Cardoso, com o intuito de refletir sobre o acesso aos lotes de terras pelos cativos, a denominada "brecha camponesa", fez um interessante mapeamento de referências ao tempo livre dos escravos ao longo da história do Brasil. A primeira menção a lotes cultivados por escravos no Brasil foi encontrada numa instrução de 1663, recebida por um administrador de uma fazenda em Pernambuco (CARDOSO, 1987, p. 92). No final do mesmo século e início do seguinte, nos anos de 1688, 1689, 1693 e 1701, o assunto fez parte de parágrafos de alvarás e ordens régias, para assegurar aos escravos o direito aos sábados livres para que pudessem cuidar de suas roças. Quem se ocupou do assunto foram os jesuítas Jorge Bencil, em 1700, e Antonil, em 1711. Também não escaparam aos apontamentos de Cardoso, os documentos utilizados por Schwartz, acerca de Engenhos da Bahia na segunda metade do século XVIII e início do século XIX; o livro de memória de Henry Koster, que administrou um engenho em Pernambuco em 1816 e 1817; os relatos de viajantes e dos naturalistas August Saint-Hilaire e Charles Darwin; bem como os textos escritos pelo fazendeiro Barão Pati de Alferes para orientar seu filho na administração da fazenda e no trato com escravos Pernambuco (CARDOSO, 1987, p. 93-105).

Ainda poderiam ser acrescentados à listagem de Cardoso, os artistas Joahann M. Rugendas e Jean Baptiste Debret, a britânica Maria Graham, o cônsul suiço J. J. Tschudi e a memorialista Maria Paes de Barros. O artista bávaro, Joahann Moritz Rugendas, por exemplo, esclareceu que "no domingo, ou dias de festas, tão numerosos que absorvem mais de cem dias do ano, os escravos são dispensados de trabalhar para seus senhores e podem descansar ou trabalhar para si próprio" (RUGENDAS, S/d, p.238).

Os escravos no Brasil não utilizavam suas folgas apenas para o cultivo de terra, como transparece nos estudos sobre a "brecha camponesa", de Cardoso; poderiam também usá-las para outras práticas que Ihes gerassem recursos materiais, tais como caça, pesca, coleta, artesanato, criação de animais 
e serviços extras. Essas atividades despertaram a atenção de alguns pesquisadores da escravidão norte-americana, que as conceitualizaram de The Internal Economy of slaver - Independent Production by Slaves, aqui denominada economia interna dos escravos ou economia independente ou economia autônoma ${ }^{4}$. Esse conceito que está presente na maioria dos trabalhos sobre a escravidão brasileira, desenvolvida, principalmente, a partir do final da década de 1970, em autores que, assim como os norte-americanos, sofreram influências das obras do historiador britânico E. P. Thompsom. ${ }^{5}$

Mesmo que, para grande parte dos historiadores brasileiros, não haja dúvidas de que havia entre os escravos a existência de desobriga, e que poderiam aproveitar esse tempo para estabelecerem uma margem econômica independente, são poucos os pesquisadores que trataram o assunto de forma sistematizada. Eduardo Silva, já constatara essa ausência, na década de 1990, prevendo que o tema poderia despertar interessantes reflexões dos especialistas:

A existência de uma margem de economia própria para o escravo promete provocar, em futuro próximo, interessantes debates entre especialistas. Embora razoavelmente estudado nos Estados Unidos e, sobretudo, no Caribe, esse aspecto do sistema colonial escravista tem sido negligenciado pela historiografia brasileira (REIS e SILVA, 1989, p. 22).

Para Silva, o motivo desse descuido estaria associado ao fato de que as correntes historiográficas mais tradicionais entendiam a prática como apenas um indicativo excepcional de liberalidade dos senhores, sem se atentarem para suas motivações mais profundas, ou enquadraram a questão de uma perspectiva lógico-abstrata, ou então entenderam que os escravos não tinham economia

\footnotetext{
${ }^{4} \mathrm{Em}$ 1991, foi organizada pelos historiadores Ira Berlin e Philip Morgan uma edição que agrupa alguns pesquisadores ligados a essa historiografia. (BELIN, Ira e MORGAN, Philip D (coord.). The Slave's Economy: Independent Production by Slaves in the Americas. Slavery and Abolition, 12:1, maio 1991).

${ }^{5}$ ALGRANTI, Leila Mezan. O feitor ausente: estudos sobre a escravidão urbana no Rio de Janeiro - 1808-1822. Petrópolis: Vozes, 1988; GUIMARÃES, Elione Silva. Economia autônoma de escravos nas grandes fazendas cafeeiras do sudeste do Brasil (zona da Mata Mineira - século XIX). América Latina em La História Econômica, $n^{\circ}$ 32, Jul/Dez de 2009; LARA, Silvia H. Campos da violência: escravos e senhores na capitania do Rio de Janeiro, 1750-1808. Rio de Janeiro: Paz e Terra, 1988; MACHADO, Maria Helena P. T. Crime e escravidão: trabalho, luta e resistência nas lavouras paulistas - 1830-1888. São Paulo: Editora Brasiliense, 1987; SCHWARTZ, Stuart. Escravos, roceiros e rebeldes. Bauru: EDUSC, 2001; SLENES, Robert W. $\mathrm{Na}$ Senzala uma flor. Esperanças e recordações na formação da família escrava. Rio de Janeiro: Nova Fronteira, 1999.
} 
própria (REIS e SILVA, 1989, p. 22). Já para Ciro Flamarion Cardoso, "isto pode decorrer de uma reação - legítima em si - contra as teses de Gilberto Freyre, Frank Tannenbaum, Stanley Elkins e outros, sobre a pretensa doçura da escravidão brasileira quando comparada com as dos Estados Unidos" (CARDOSO, 1979, p. 139). As reações a que se referem Cardoso, estão presentes nos trabalhos escritos pelo grupo de historiadores e sociólogos conhecidos como Escola Sociológica Paulista. ${ }^{6}$

De qualquer maneira, as considerações de Silva não destoam muito da situação atual, uma vez que o tema em si ainda não teve grandes destaques nos debates historiográficos brasileiros. Entretanto, o assunto surge como coadjuvante em estudos sobre diferentes temáticas da escravidão brasileira para explicarem a sua problemática central. ${ }^{7}$ Assim, por exemplo, a desobriga e as atividades econômicas independentes são destacadas em textos de Robert Slenes, quando há certos nexos com a formação e manutenção dos laços familiares entre os escravos. O casamento significaria aos escravos possibilidade de melhoras em suas vidas materiais, pois a união proporcionaria divisão de trabalho familiar e o resultado das colheitas, caças, pescas, coletas e criações de animais suplementariam suas dietas, além de gerar a acumulação do excedente:

A renda monetária proveniente de todas estas fontes, além de ampliar as possibilidades de "consumo" e, dessa forma, ajudar a viabilizar projetos de vida e redes de solidariedade dentro da escravidão, também poderia possibilitar poupança, (...), havia a possibilidade de uma "acumulação" mais significativa, que permitisse a compra de liberdade (SLENES, 1999, p.197).

Se o trabalho de Slenes é um exemplo de pesquisa sobre família escrava, na qual são destacadas algumas questões envolvendo práticas econômicas, o de Maria Helena Machado pode servir para tipificar aqueles que relacionam resistência (violência) e à autonomia escrava. Ao estudar a

${ }^{6}$ BASTIDE, Roger e FERNANDES, Florestan. Brancos e Negros em São Paulo. 3a. Edição. São Paulo: Nacional, 1971; CARDOSO, Fernando Henrique. Capitalismo e escravidão no Brasil Meridional. São Paulo: Difusão Européia do Livro, 1962; COSTA, Emília Viotti da. Da senzala à colônia. 4a. Ed. São Paulo: Editora da Unesp, 1997.

${ }^{7}$ Especialmente: MACHADO, Maria Helena P. T. Crime e escravidão: trabalho, luta e resistência nas lavouras paulistas - 1830-1888. São Paulo: Editora Brasiliense, 1987; SLENES, Robert W. $\mathrm{Na}$ Senzala uma flor. Esperanças e recordações na formação da família escrava. Rio de Janeiro: Nova Fronteira, 1999. 
resistência escrava na região de Campinas e Taubaté, Machado percebeu que a desobriga escrava seria um direito consolidado entre os escravos e que, para ser mantido, exigia políticas cotidianas, nas constantes negociações entre escravos e senhores, cada qual fazendo uso dos elementos que tinham a sua disposição. A historiadora destacou, por exemplo, uma história relacionada à imposição de limites por parte de escravos, ocorrida em uma fazenda de Campinas em 1876, quando Anna, Benedicto, Martinho, João e Caetano justificaram ter assassinado seu senhor porque "era mao, fazia-os trabalhar domingos e dias santos sem pagamento" (MACHADO, 1987, p. 118). Atitudes como essas seria, na maioria das vezes, o último recurso utilizado pelos escravos e deveria ocorrer quando todos os outros já haviam falhado. O senhor dos cinco escravos campineiros pagou com a própria vida por não ter respeitado um direito entendido pelos cativos como consolidado.

A economia independente dos escravos não deve somente ser pensada como uma estratégia de controle senhorial, conotando apenas como "função ideológica", pois retiraria a peça do mecanismo de movimentação da engrenagem do processo histórico, que é luta de classes, na qual os escravos, assim como os senhores, participavam como agentes históricos na construção do processo social de que faziam parte. Se a desobriga para os senhores tinha a função de conter e facilitar a cooperação dos escravos, para estes, ela se tornava, ao longo do tempo, um acordo e prática que deveriam ser respeitados, pois Ihes traziam bastantes vantagens, muitas das quais serviam de importantes elementos para atenuar os reveses em que suas condições jurídicas os colocavam e também para diversos projetos de vidas, dentre os de maior expressão, a compra de suas próprias liberdades ou de algum parente (REIS e SILVA, 1989, p.22-31).

Como vários outros historiadores de sua geração ${ }^{8}$, Robert Slenes e Maria Helena Machado veem na desobriga e na economia independente dos

\footnotetext{
${ }^{8}$ Destaque para os seus estudos sobre as revoltas e rebeliões escravas na Bahia de João José Reis; os trabalhos de Flávio Gomes sobre os quilombos; Maria Cristina Cortês Wissenbach, com as análises sobre a vivência de escravos e forros e os estudos dos escravos rurais de Silvia Lara. (GOMES, Flávio dos Santos. A hidra e os pântanos: quilombos e mocambos no Brasil (Séculos XVII - XIX). São Paulo: Cia das Letras, 2007; LARA, Silvia H. Campos da violência: escravos e senhores na capitania do Rio de Janeiro, 1750-1808. Rio de Janeiro: Paz e Terra, 1988; REIS, João José. Rebelião escrava no Brasil: a história do levante dos malês (1835). São Paulo: Brasiliense, 1986; WISSENBACH, Maria Cristina Cortez. Sonhos africanos, vivências ladinas:
} 
escravos um caráter político, um espaço de conflitos entre senhores e escravos, onde estes buscavam, sempre que possível, colocar limites à exploração senhorial e maximizar suas vantagens. Esses trabalhos aproximam-se dos desenvolvidos pela historiografia norte americana sobre a economia independente dos escravos (The Internal Economy of slaver - Independent Production by Slaves), tanto do ponto de vista metodológico, pelo uso de vasta base empírica, quanto teórico, pelas leituras do processo histórico com inspiração nas obras do marxismo cultural do historiador britânico E. P Thompson (BELIN e MORGAN, 1991).

Se os trabalhos que se referem à economia independente dos escravos, de maneira indireta, forma um conjunto relativamente grande, o mesmo não se pode dizer sobre as pesquisas que a tiveram como temática central, pois são bastante modestas, destacando apenas os trabalhos sobre "brecha camponesa", de Ciro Flamarion Cardoso, as pesquisas sobre a economia independente dos escravos da zona da Mata Mineira, no século XIX, de Elione Guimarães e os textos de Stuart Schwartz, que, aliás, foi o pioneiro, ao chamar atenção à possibilidade de os escravos brasileiros transformarem os momentos que tinham para si em autonomia material, utilizando-se de uma carta escrita por um grupo de escravos fugitivos do Engenho de Santana, em 1789, na Bahia, mediante a qual impunham condições para retornarem à fazenda. Merecem destaque os seguintes trechos da carta:

Em cada semana nos há de dar os dias de sexta-feira e sábado para trabalharmos para nós, não tirando um destes dias por causa de dia santo"; "Podemos plantar nosso arroz onde quisermos, e em qualquer brejo, sem que para isso peçamos licença, e podemos cada um tirar jacarandá ou qualquer outro pau sem darmos parte a isso (SCHWARTZ, 1997).

Graças a Schwartz, "O tratado proposto a Manuel da Silva Ferreira pelos escravos durante o tempo em que se conservavam levantados (c.1789)", tornouse bastante conhecido por pesquisadores e público em geral. Schwartz ainda publicaria outros trabalhos envolvendo a independência econômica e a 
autossuficiência dos escravos ${ }^{9}$, dentre os quais, pode-se destacar o artigo de 1982, em que tratou sobre as plantations pertencentes aos beneditinos em várias regiões brasileiras, no qual constatou que havia ordens para que todas as propriedades beneditinas reservassem um dia útil semanal aos escravos para que eles pudessem cuidar do cultivo em seus lotes de terras, o que poderia gerar, com a venda de excedentes, uma renda monetária (SCHWARTZ, 2001).

Aliás, segundo Schwartz, era comum nas propriedades beneditinas que os escravos legassem seus lotes a familiares ao morrerem. Para ele, o acesso à terra entre os escravos, ao mesmo tempo em que desestimulava as fugas e outros tipos de resistências entre os escravos, desonerava um pouco os proprietários com relação à alimentação dos cativos e também Ihes dava uma espécie de conforto psicológico com relação às agruras da realidade escravista (SCHWARTZ, 2001). Considerações, até certo ponto, parecidas com as de Ciro Flamarion Cardoso, em seus textos "Brecha camponesa no sistema escravista" e Escravo ou Camponês?, nos quais analisou o acesso dos escravos a lotes de terras para cultivo de roças para consumo próprio e venda do excedente para suprir inclusive a demanda do mercado interno (CARDOSO, 1979 e 1987).

A partir do conceito "brecha camponesa", Cardoso observou que, do ponto de vista senhorial, a concessão serviria tanto para ligar os escravos à terra, evitando possíveis fugas, quanto para transferir-lhes o ônus de sua própria manutenção, o que minimizava os custos com seus plantéis. Enquanto que, para os cativos, a "possibilidade de dispor de uma economia própria era importante econômica e psicologicamente". Cabe, ainda, ressaltar que entre os primeiros trabalhos e o livro de 1987, há certa mudança de postura, com relação ao papel que Cardoso dava à "brecha camponesa", pois, neste último, ela passa a ser vista com potenciais elementos de modificação das estruturas do sistema escravista (CARDOSO, 1979 e 1987).

Apesar de, nas obras de Cardoso, estar presente a ideia de que o gozo do tempo livre para o cultivo de lotes de terra significou para muitos escravos um espaço conquistado e que, ao longo do tempo, passou a ser uma espécie de

9SCHWARTZ, Stuart B. Resistance The plantations of St. Benedict: the Benedictine sugar Mills of colonial Brazil. The Americas, Vol. 39, No. 1: 01-22, Jul. 1982; Id. Sugar plantation in the formation of Brazilian society, 1550-1883. Cambridge: Cambridge University Press, 1985; Id. Escravos, roceiros e rebeldes. Bauru: EDUSC, 2001. 
direito adquirido e que, muitas vezes, para mantê-lo foi necessária a tensão e o conflito com os senhores, o que acaba prevalecendo em suas análises é que quem mais se favoreceu com a prática da "brecha camponesa" foram os senhores, já que a produção de alimentos, além de baratear os custos com alimentação dos cativos também os apaziguava. Além do que, seria uma concessão que os senhores poderiam revogar a qualquer momento, o que colocaria os escravos em uma condição de refém de suas próprias conquistas.

Os estudos de Cardoso, apoiados principalmente em relatos de algumas testemunhas contemporâneas ${ }^{10}$ e na bibliografia que trata da ocorrência da brecha camponesa no Sul dos Estados Unidos, Caribe ${ }^{11}$ e Brasil ${ }^{12}$, de certa maneira, apenas sinalizou a existência de uma potencialidade dinâmica na brecha camponesa, e de que ela seria portadora de conflitos. Os seus textos apresentam uma carência de base empírica que os fazem parecer mais ensaios (sínteses) do que textos historiográficos, o que, obviamente, não lhes retira o mérito e o papel de referência bibliográfica brasileira para quem pretende estudar o assunto.

O trabalho sobre a "brecha camponesa" gerou bastantes críticas, sendo que as mais contundentes foram as de seu contemporâneo Jacob Gorender, para quem o acesso e cultivo de lotes de terras pelos escravos não tinham um papel de destaque como queria Ciro Flamarion Cardoso, e nem se poderia considerar que a produção e comercialização de alimentos pelos cativos tivessem caráter estrutural, generalizante e estável. Para Gorender, as plantações dos escravos seriam sazonais e poderiam sofrer interferência da demanda por mão de obra nas lavouras e usinas de açúcar no tempo da safra, além do que, não alteravam em nada as estruturas e dinâmicas do processo histórico escravista (GORENDER, 1991, p.70-86). Percebe-se, conforme observou Robert Slenes, um contraste bastante nítido entre o posicionamento atual de Cardoso e o de Gorender, pois, enquanto que este nega qualquer importância à luta de classes no escravismo, o primeiro entende a luta entre

\footnotetext{
${ }^{10}$ Destaque para ANTONIL, André João. Cultura e opulência do Brasil. Belo Horizonte/São Paulo: Editora Itatiaia/EDUSP, 1982; KOSTER, Henry. Trabels in Brazil. $2^{\mathrm{a}}$ Edição, London: Çongman, Hurst, Rees, Orme and Brown, 1817.

${ }^{11}$ Entre eles: LEPKOWSKI, Tadeunz. Haití. Havanam: Casa de las Américas, 1968; MINTZ, Sidney W. Caribbean Transformations. Chicago: Aldine Publishing Company, 1974.

${ }^{12} \mathrm{SCHWARTZ}$, Stuart B. The plantations of st. Benedict: the Benedictine sugar of colonial Brasil. The Americas, 39, 1:22, jul 1982.
} 
senhores e escravos em torno da brecha camponesa como um elemento central da formação do "modo de produção escravista colonial" (SLENES, 1999, p.197/198).

Após um hiato de aproximadamente duas décadas na historiografia, a economia entre os escravos brasileiros ressurge sob as análises de Elione Guimarães, que estudou a economia autônoma dos escravos no Vale do Paraíba mineiro, com ênfase no acesso e no cultivo de lotes de terras. ${ }^{13} \mathrm{~A}$ pesquisa de pós-doutorado, na Universidade Federal Fluminense, que, em 2009, ganhou uma versão em livro, foi o trabalho mais expressivo de Guimarães para o debate historiográfico nessa temática. A autora tem como ponto de referência empírica o inventário e o testamento de um grande fazendeiro do município mineiro de Mar de Espanha, que faleceu em 1867. Graças às muitas contestações que foram sendo feitas com relação às contas dos diferentes administradores do espólio, foi possível acompanhar a dinâmica das fazendas deixadas pelo finado por mais de 20 (vinte) anos, em especial, sobre o acesso à terra e as economias independentes dos escravos (GUIMARÃES, 2009).

O trabalho de Guimarães tem seus méritos não somente por ter colocado a economia autônoma dos escravos nos focos das atenções, mas também por ter recuperado várias histórias de luta de escravos e, principalmente de libertos com senhores para garantir o direito de acesso e usufruto da terra que, em alguns casos, haviam Ihes sido legado, principalmente quando os senhores possuíam algum grau de parentesco com indivíduos negros, como, por exemplo, é o caso destacado pela autora, do Barão de Louriçal, que como morreu solteiro e fez o reconhecimento de paternidade em testamento, no qual instituiu por herdeiros filhos mestiços que teve com 5 (cinco) de suas escravas (todas alforriadas em testamento), às quais ele também deixou legado. Entre as propriedades, destacavam-se a fazenda Porto Alegre (Itaperuna - RJ), que foi herdada por Generosa, com quem o Barão tinha 7 (sete) filhos e a fazenda do

\footnotetext{
${ }^{13}$ GUIMARÃES, Elione Silva e MOTTA, Márcia Maria Menendes. Campos em Disputa. História Agrária e Companhia. São Paulo: Annablume, 2007; Id. Economia autônoma de escravos nas grandes fazendas cafeeiras do sudeste do Brasil (zona da Mata Mineira - século XIX). América Latina em La História Econômica, $\mathrm{n}^{\circ}$ 32, Jul/Dez de 2009; Id. Múltiplos Viveres de Afrodescendentes na Escravidão e no Pós-Emancipação. Família, trabalho, terra e conflito (Juiz de Fora - MG, 1828-1928). São Paulo: Annablume, 2006 e Id. Terra de Preto. Usos e ocupações da terra por escravos e libertos (Vale do Paraíba mineiro, 1850-1920). Niterói: Editora da UFF, 2009.
} 
Alpes em Mar de Espanha - MG (GUIMARÃES, 2009, 0.68).

Além disso, Guimarães propôs a ampliação do conceito "Terra de Preto", cunhado pelo antropólogo Alfredo Wagner Berno de Almeida, que diz respeito a terras onde permanecem os descendentes de ex-escravos e de quilombolas, mas que não inclui aí as terras que eram concedidas aos escravos para que cultivassem em seu tempo livre (ALMEIDA, 1996). Para a autora, o conceito também deve abranger "a possibilidade de acesso à terra pelos escravos, por usufruto, mediante o exercício de suas atividades agrícolas autônomas" (GUIMARÃES, 2009, p.132).

Os textos de Elione Guimarães, de uma maneira geral, possuem uma aproximação do ponto de vista da orientação conceitual, teórica e metodológica daqueles estudos sobre a escravidão brasileira na qual a economia independente dos cativos é referenciada para auxiliar na compreensão de suas problemáticas $^{14}$, o que é evidenciado tanto pelo diálogo bibliográfico estabelecido pela autora com a maioria deles, como pela inspiração, que a própria autora diz ter, das obras de Thompson, autor que influenciou a maioria daqueles autores em suas análises sobre a escravidão brasileira (GUIMARÃES, 2009, p.25)

Ciro Flamarion Cardoso, em 1979, observou que "a pouca atenção prestada neste país pelos historiadores à brecha camponesa parece indicar certo ceticismo relativo a sua importância" (CARDOSO, 1979, p.138). Quase uma década depois, sua percepção a respeito das pesquisas sobre o tema continuava desanimadora. Lamentava ele, "é muito difícil redigir uma síntese relativa ao nosso tema, no tocante ao caso brasileiro, devido que (...) apresenta um caráter fragmentário e notório insuficiente" (CARDOSO, 1987, p.91). Alguns anos depois, Eduardo Silva chegou a um entendimento parecido, conforme já citado anteriormente, mas não tão desanimador, pois entendia que o assunto deveria ocupar a atenção da historiografia brasileira em um futuro próximo (REIS e SILVA, 1989, p.22).

\footnotetext{
${ }^{14}$ GOMES, Flávio dos Santos. A hidra e os pântanos: quilombos e mocambos no Brasil (Séculos XVII - XIX). São Paulo: Cia das Letras, 2007; LARA, Silvia H. Campos da violência: escravos e senhores na capitania do Rio de Janeiro, 1750-1808. Rio de Janeiro: Paz e Terra, 1988; REIS, João José. Rebelião escrava no Brasil: a história do levante dos malês (1835). São Paulo: Brasiliense, 1986; WISSENBACH, Maria Cristina Cortez. Sonhos africanos, vivências ladinas: escravos e forros em São Paulo (1850-1888). São Paulo: Hucitec/História Social, USP, 1998.
} 
Assim, passados pouco mais de 3 (três) décadas, desde do que escreveu Cardoso, o espaço ocupado pela margem econômica independente do escravo continua, se não pelos estudos em que o assunto é secundário, quase inexpressivos, tendo sua representação atual apenas nas pesquisas de Elione Guimarães, e isso, como nos faz supor os documentos de arquivos, jornais da época, relatos de viajantes e memorialistas, está mais relacionado ao olhar historiográfico à objetividade das realidades experimentadas pelos escravos.

Nesse sentido, tentar-se-á pontuar algumas situações e indícios que realce a importância de se colocar a "desobriga escrava" e suas implicações não como um assunto isolado, mas como a problemática central, buscando os seus nexos com as margens econômicas independentes e com o sentido político que elas poderiam tomar no processo histórico e social que ela compunha.

Algumas fontes relativas a Itu e observações de alguns viajantes indicam que os escravos poderiam ainda dispor do "tempo que tinham para si" para atividades lúdicas e de sociabilização. Rugendas, por exemplo, observou que esse aproveitamento poderia começar na noite anterior aos dias de folga, pois "muitas vezes que os negros dançam sem parar noites inteiras, escolhendo por isso, de preferência, os sábados e as vésperas dos dias santos" (RUGENA, S/d, p.238). Cena que também é recorrente nos relatos de Maria Graham, que, quando esteve em uma fazenda da Província do Rio de Janeiro em 1822, presenciou a ocorrência de encontros festivos em uma noite de sábado na senzala. Ao ouvir sons de música à noite, ela "foi logo às cabanas dos escravos casados, onde se realizava a função e encontrei os grupos a brincar, a cantar e a dansar à luz da lua" (GRAHAM, 1956, p.232).

Apesar de Itu ter recebido a visita de alguns viajantes, artistas e naturalistas, nenhum deles registrou cenas em que os escravos estivessem produzindo para si ou em momentos lúdicos. Entretanto, a documentação cartorária, em especial, os processos criminais ${ }^{15}$ relativos à segunda metade do século XIX, trazem bastantes indícios sobre o assunto. A necessidade das autoridades em entender o crime e construir a culpa no processo criminal, registra, pelas falas das testemunhas, informantes, vítimas e réus, trechos da vida íntima e do cotidiano de alguns escravos, que aparecem em seus momentos

${ }^{15}$ Composta pelas seguintes séries documentais: Sumário Crime, Sumário de Culpa, Autos Crimes, Recurso Crime e Jury. 
de folgas realizando trabalhos extras, comercializando, divertindo-se, festejando, namorando, circulando por ruas, estradas, bares e espaços públicos e privados de Itu.

Com relação ao trabalhar para si, entre as diferentes histórias preservadas no Arquivo do Museu Republicano de Itu, uma merece destaque, pois evidencia diversas possibilidade de os escravos aproveitarem o "tempo que tinha para si” para obterem economia própria. Vamos ela: José Garcia, foi testemunha nos Autos crimes relativos ao assassinato de um escravo da Baronesa de Itu, que ocorreu em sua venda na rua do Pirai em 1861. A confusão teria contado com mais cativos desta, e outros dois escravos do Capitão Francisco Pereira Mendes. Segundo José Garcia:

no domingo, as quatro horas e meia, mais ou menos da tarde, estavão na venda d'elle depoente três negros, dos quais não conhecia nem hum, e tendo comprado feijão de um delles, dera dinheiro, hum outro quis tomar o dinheiro, e entrarão em huma questão a respeito do balaio em que estava o feijão, e que sahindo para fora apareceu hum quarto negro, que também não o conhece, mas que era rapas novo, entrou em briga com dous dos que estiverão dentro, e que estavão em rusga do balaio, e puxou por huma faca, então hum dos três, o que estava de ponche disse aos dous primeiros que retirasse, que não fizesse barulho, o mesmo dizia ao rapas que estava com a faca na mão, e nesta occasião elle testemunha entrou para dentro, e nada mais vira. ${ }^{16}$

O "rapas novo" era Generoso, escravo da Baronesa de Itu. Também relataram o acontecido nos Auto, alguns escravos: Perpétua informou que "retirando-se para o sitio, e na rua do Pirahi, defronte a casa de José Garcia vio que estavão em disputa e embriagado os escravos Isac e Frederico, este de Francisco Pereira Mendes e aquelle da Baronesa de Itu, que Isac chamou a Generoso seu cunhado para ajudá-lo na briga". ${ }^{17} \mathrm{O}$ crioulo Henrique, também escravo da Baronesa, estava na "casa de Jose Pinto, rachando lenha, [quando] ouvio gritar Perpetua, e conhecendo a voz della, sahio para ver o que era, então

\footnotetext{
${ }^{16}$ Autos Crimes. Autora: a Justiça/Réu: Generoso, escravo da Baronesa de Itu. Pasta 79. 1861. Arquivo/Museu Republicano de Itu/USP, Fls. $7 \mathrm{f}$ e v.

${ }^{17}$ Ibid., Fls. $8 f$.
} 
ella disse que Generoso tinha faqueado Gabriel, e que elle hia correndo para o caminho do sitio". ${ }^{18}$

Se não são todos, alguns daqueles escravos deveriam ser sócios no balaio de feijão, produto que, como lembrado pelo memorialista ituano Nardy, era muito comum nos pratos ituanos, e era acompanhado de "arroz, verdura e carne. O feijão era o prato de substância. "Uma mesa sem feijão não tem graça - dizia-se" (NARDY FILHO, v.4, 2000, p.180). O mantimento, segundo Câmara Cascudo, era indispensável para a vida das pessoas, que havia até ditos populares que o usava como referência: "pirões e feijões" e "não ganha pros feijões" (CASCUDO, 2001, p.443/444).

Quando passou por Itu, o viajante Saint-Hilaire observou que, já nas primeiras décadas do século XIX, o feijão estava presente nas terras ituanas, é que "cultiva-se no distrito de Itu um pouco de café, de algodão, de chá e de óleo rícino, bem como uma quantidade de milho e feijão" (SAINT-HILAIRE, 1976, p.175).

Os escravos que tinham acesso a lotes de terras em Itu, e aqueles que estavam na venda de José Garcia, deveriam conhecer o potencial comercial do feijão e lançavam mão de seu cultivo para estabelecer margens econômicas independentes com sua comercialização. E quem garante que das plantações de feijão vistas por Saint-Hilaire, algumas não poderiam ser de escravos? A única clareza que se pode ter é que o cultivo e comercialização de feijão em Itu era uma possibilidade aberta para que escravos pudessem transformar seus momentos de desobriga senhorial em recurso monetário ou material, já que seria um produto de grande aceitação popular e uma roça de feijão poderia render até 3 (três) colheitas por ano, o que o tornava um produto bastante atraente aos olhos de quem desejasse lucros (SANTOS, 1995, p.125).

Além da comercialização de feijão, os autos crimes, em que Generoso é réu, sugerem ainda duas outras possibilidades de ganho pelos escravos, quais sejam, o corte de ponta de cana e rachar lenhas. A primeira surge na resposta dada por ele ao ser questionado "se costumava andar com facas", o que respondeu: "não senhor, e nesse dia estava de facca porque ia cortar pontas de

${ }^{18}$ AUTOS CRIMES. Autora: a Justiça/Réu: Generoso, escravo da Baronesa de Itu. Pasta 79. 1861. Arquivo/Museu Republicano de Itu/USP, Fls. 11v. 
canas para vender". ${ }^{19}$ Se é verdadeira ou não, ou se o réu a criou com o intuito de atenuar sua culpa, isso deveria caber às leituras do Juiz, o interessante aqui é pensá-la como uma expressão do possível, mesmo que, de fato, ele não usasse a faca para cortar pontas de cana, deveria ter pinçado o elemento da realidade que o cercava, para que seu discurso pudesse fazer sentido aos ouvidos de seus interlocutores.

$\mathrm{Na}$ verdade, a resposta de Generoso é interessante no sentido de apontar para um campo de atividades que existiria em Itu, o que pode ser desvendado em outras fontes de informações, como os Códigos de Posturas e Autos Crimes, que apontam para a existência de atividades semelhantes a de cortar ponta de canas. É possível visualizar uma demanda de trabalho e produto, que assim como as pontas de canas, estaria relacionada à alimentação de cavalos e muares, cujas oportunidades devem ter sido muito bem aproveitadas por alguns escravos em Itu, como fazia Miguel, o protagonista dos Autos Crimes que foram instaurados em 1863, para apurar suas responsabilidades sobre o sumiço de uma mala com dinheiro e papéis da casa de Joaquim Januário. Conforme testemunhou o chaveiro do Cemitério, "o indiciado segundo acostumava pedio-lhe a chave do cemitério e foi lá cortar capim, voltou logo depois trazendo huns papeis, que achara, segundo disse, no fundo do cemitério". 20 Pelo que informa o Promotor, em sua denúncia, o ponto onde Miguel vendia o capim era atrás da Capela de Santa Rita. ${ }^{21}$

No artigo 73 dos Códigos de Posturas, relacionado à regulamentação de negociações com escravos em Itu, quando é feita a menção às exceções, a venda do capim ganha destaque.

Artigo 73, Fica Prohibido: $\S 3^{\circ}$ A compra ou troca á noite de qualquer gênero ou espécie, ainda que permittidos, com escravos que não apresentarem autorisação dos seus senhores. Excepetuão-se os que se empregão na venda de capim e quitandas pelas ruas. ${ }^{22}$

Dessa maneira, assim como Miguel, muitos outros escravos devem ter feito do comércio de capim um meio de ganhar dinheiro, tendo em vista que

\footnotetext{
${ }^{19}$ Autos Crimes. Autora: a Justiça/Réu: Generoso, escravo da Baronesa de Itu. Pasta 79. 1861. Arquivo/Museu Republicano de Itu/USP, Fls. 16v.

${ }^{20}$ Autos Crimes. Autora: a Justiça/Réu: Miguel, escravo da Herança de Felis Brasil. Pasta 82. 1863. Arquivo/Museu Republicano de Itu/USP, FI. 23v.

${ }^{21}$ Ibid., Fl. 3v.

${ }^{22}$ Códigos de Posturas de Ytu de 1873, FI. 273.
} 
tinham a sua disposição um contexto propício para essa atividade, tanto que os Códigos de Posturas de Itu a regulamentava.

Rachar lenha parece ter sido uma atividade comum em Itu, e era justamente isso que o escravo Henrique, da Baronesa de Itu, estava fazendo na casa de José Pinto no domingo, enquanto Generoso e seus companheiros estavam na venda de José Garcia negociando o balaio de feijão. Pelo que conta Nardy, a figura do rachador de lenha parece ter sido bem comum na rotina dos moradores de Itu, sobre os "Tipos e usos que desapareceram", escreveu que

O rachador de lenha ia pelas ruas levando ao ombro o seu machado largo e bem afiado; parava aqui, parava ali, às vezes de casas em cujas frentes visse amontuada uma carga de lenha; às vezes encontrava um carro de bois ou uma carriola carregada de lenha e se punha a acompanhálo até onde fosse descarregado. Vieram os fogões elétricos e a carvão, as lenharias e serrarias passaram a oferecer à população lenha aparada, os rachadores de lenha foram desaparecendo (NARDY FILHO, v.4, 2000, p.174).

Os Códigos de Posturas, em seu artigo 65, que proíbe o uso de armas de defesa sem licença, menciona o lenheiro em sua lista de profissões, o qual poderia fazer uso das referidas armas.

Artigo 65. É prohibido nos povoados deste Município, sem licença legal, o uso de armas de defesas. Exceptuão-se: $\$ 4^{\circ}$. Os carreiros, tropeiros, boiadeiros, carroceiros, lenheiros, porqueiros e trabalhadores de roça, durante o exercício de suas occupações, das que forem notoriamente necessárias ás mesmas occupações ou trabalhos. ${ }^{23}$

Não deve ser difícil visualizar cenas em que escravos estariam rachando lenha em quintais de Itu para alimentar as chamas dos fogões a lenha que cozinhavam o arroz, feijão, carne, pirão e outros alimentos que faziam do repertório alimentar da gente ituana da segunda metade do século XIX.

O ganho poderia servir para gastos imediatos ou para acumulação de capital, dos quais poderia servir tanto para uma futura compra de liberdade ou quem sabe a obtenção de uma propriedade privada.

$\mathrm{Na}$ cidade de Itu, entre 1850 e 1871, das 89 cartas de alforrias conquistadas pelos escravos, 20 envolviam pagamento em dinheiro aos

\footnotetext{
${ }^{23}$ Códigos de Posturas de Ytu de 1873, FI. 273.
} 
senhores. ${ }^{24} \mathrm{Em}$ documentos relativos à região de Itu, localizou-se referência apenas a outro cativo comprando um imóvel em 17 de maio de 1864, na Vila de Indaiatuba, onde Severino, escravo de José Tibiriça Piratininga comprou de Maria José de Amaral Campos, pelo valor de 44 mil réis, "uma casa de morada coberta de telha com seu quintal (...) situada entre as duas estradas que segue desta para a cidade de Itu"25.

No mesmo ano em que o escravo de José Tibiriça comprara uma casa em Indaiatuba, falecia em Itu a preta forra Francisca Ferras que deixou de herança para o seu único herdeiro, o seu então marido Antonio Quadros, preto forro, conforme consta em seu inventário:

Huma casinha na rua Santa Rita, por $50 \$ 000$. huma dita na rua Santa Cruz, por $70 \$ 000 .^{26}$

Infelizmente não consta qualquer indicativo sobre se no tempo em que adquiriram ou construíram as casas a preta Francisca e seu marido Antônio ainda eram escravos ou já haviam se alforriado. De qualquer maneira, eles além de terem tido força para acumularem pecúlio necessário para comprar suas alforrias, ainda foram capazes de adquirir propriedade privada mediante a seus esforços.

Como já dito anteriormente, os escravos poderiam também ocupar o tempo que estavam desobrigados de prestarem serviços a seus senhores com lazer. Há vários casos de escravos aproveitando suas desobrigas para a diversão, participando de "funções" ou "pagodes" aos sábados à noite, pode-se citar os exemplos que ocorreram na Senzala de Martha em $1874^{27}$, ou a que ocorreu na Senzala de Francisco, em uma noite de sábado de $1862^{28}$, que só se materializaram porque houve a morte de alguém e foi necessário se instaurar procedimentos investigativos e jurídicos.

\footnotetext{
${ }^{24}$ Livro de Notas (1847-1850). FCNI 006 (1840-1858): Arquivo Histórico do Museu Republicano e Livro de Notas (1868-1880). FCNI 009 (1868-187): Arquivo Histórico do Museu Republicano. ${ }^{25}$ Livro de Escrituras no 05 (1859-1863). Arquivo Público Municipal. Fundação Pró-Memória, Indaiatuba - SP, Fls. 71 v e $72 \mathrm{fe} \mathrm{v}$.

${ }^{26}$ Inventário (Inventariada: Francisca Ferrás, preta forra). Pasta 83A, 1864: Arquivo Histórico do Museu Republicano - Itu, Fls. 17v.

${ }^{27}$ Processo Crime (A Justiça/Autora - José Camareno/Réu). 1874. Cópia digitada pertencente a "Coleção Nilson Cardoso de Carvalho". Arquivo Público Municipal Nilson Cardoso de Carvalho Fundação Pró-Memória de Indaiatuba, Fls. 12. (Autos de perguntas ao réu).

${ }^{28}$ Processo Crime (Autor - A Justiça; Réu - Vicente, José e Athanasio). Pasta 79, 1862: Museu Republicano - USP - Itu - SP, Fls. 04.
} 
No caso relativo a Martha, foi por que o feitor José Camarero teria assassinado a escrava Antonia, em 1874, na vila de Indaiatuba. Segundo o réu, os motivos que o levaram a cometer o assassinato, é:

por the haver contado Faustino que tendo havido no sábbado uma funcção na senzala de Martha, vio Antonia e Chico filho de Martha juntos naquelle lugar, tendo aquelle apagado a luz para ficarem juntos no escuro. ${ }^{29}$

Já os Autos Crimes, de 1862, o escravo Galdino é acusado pelo assassinato de Salvador, o seu companheiro de cativeiro. O fato, segundo transcorre nas páginas amareladas dos Autos, deu-se numa noite de sábado, quando os dois, após participarem de um "brinquedo de batuque", numa senzala, foram, como de costume, deitar na casa de engenho quando o primeiro com uma foice assassinou seu companheiro. ${ }^{30}$

As festas nas senzalas também poderiam contar com a presença de quilombolas. Alguns que viviam nas proximidades do sítio da Ponte em Itu, no início da década de 1860, costumavam frequentar os "pagodes" que aconteciam na senzala do escravo Francisco. Pelos relatos, fizeram isso ao longo dos dois anos que permaneceram refugiados naquela região, sem que tivessem qualquer objeção do senhor e feitor do local. Eles, inclusive, faziam do local um ponto de apoio para a manutenção de suas fugas ${ }^{31}$. A farra só acabou para alguns porque houve a morte de um dos quilombolas e a polícia entrou em ação e prendeu os assassinos. ${ }^{32}$

Entretanto, não era somente as "funções" e "pagodes" em senzalas que atraiam os escravos em seus momentos de "desobriga", eles poderiam ir às tabernas jogar e beber; gostos estes que chamaram a atenção das autoridades locais, que tentaram normatizar algumas dessas atividades de lazer sob a forma de Posturas Municipais:

\footnotetext{
${ }^{29}$ Tribunal do Jury (A Justiça/Autora - José Camareno/Réu). 1874. Arquivo Público Municipal Fundação Pró-Memória de Indaiatuba, Fls. 12.

${ }^{30}$ AUTOS CRIMES. Autora: a Justiça/Réu: Galdino, escravo de Salvador Nardy. Pasta 79, 1862. Arquivo/Museu Republicano de Itu/USP.

${ }^{31}$ Esse Processo Crime serviu de apoio empírico para o terceiro capítulo - Suspendendo o cativeiro, da dissertação de mestrado Praticando a liberdade: um estudo sobre resistências escravas em Itu (1850-1873), que defendi em 2004, no programa de Pós Graduação em História da Universidade Federal de Uberlândia.

${ }^{32}$ Processo Crime. Autor - A Justiça; Réu - Vicente, José e Athanasio. Pasta 79, 1862: Museu Republicano - USP - Itu - SP.
} 
Art. 69. Os donos das casas dos jogos lícitos, que consentirem escravos e pessoas livres menores soffrerão multa de $10 \$ 000$.

Art.73. Fica prohibido:

$\S 6^{\circ}$. Batuques, cateretês, vaias, que pertubem a moralidade e socego público.

Art. 74. Os escravos que depois do toque de recolhida forem encontrados vagando pelas ruas sem bilhetes de seus senhores, ou e tabernas, botequins, ou jogando, serão presos e entregues a seus senhores no dia seguinte, depois de paga a carceragem.

Art.75. Fica prohibido a escravos a dança, sem a competente licença, nas ruas ou subúrbios da Cidade, Freguezia e povoação de Salto, e os jogos de qualquer qualidade que sejão... ${ }^{33}$

Os indícios sobre o lazer entre os escravos, assim como os sobre práticas produtivas, também aparecem nos processos criminais, com a função de reconstituir o contexto em que se deu o fato gerador do processo. Assim, só foi possível ter a informação documentada de que, em uma noite de sábado de 1862, houve um pagode na senzala do escravo Francisco porque alguns quilombolas assassinaram um de seus companheiros pouco depois de terem se retirado do local. ${ }^{34}$ Caso não tivesse ocorrido o crime, a memória sobre aquela noite de sábado na senzala de Francisco teria caído no esquecimento. Quantos outros "pagodes", "funções" ou "batuques" não teriam ocorrido naquela ou em outras senzalas, mas não foram documentadas, simplesmente pelo fato de tudo ter fluido sem a necessidade de qualquer intervenção das autoridades e de seus registros?

Destarte, o aproveitamento do tempo que tinham para si, tanto para atividades econômicas independentes quanto para o lazer, não foi privilégio apenas daqueles escravos que a presente pesquisa teve acesso pelas fontes documentais. Muitos outros devem ter plantado, pescado, coletado, colhido, caçado, dançado, prestado serviços extras, jogado e frequentado botequins, só que, de forma diferente, não houve incidentes ou situações que ensejassem necessária a intervenção oficial. Dessa maneira, parece que, o que seria possível a alguns escravos, poderia ser aos demais. Contudo, do ponto de vista metodológico-conceitual faz sentido uma reflexão inspirada na ideia de que "a

\footnotetext{
${ }^{33}$ Código de Posturas do Município de Itu - 1873, p. 273 e 274.

${ }^{34}$ Processo Crime (Autor - A Justiça; Réu - Vicente, José e Athanasio). Pasta 79, 1862: Museu Republicano - USP - Itu - SP, Fls. 04.
} 
expressão individual ocorre dentro de um idioma geral" (DARTON, 2006, p.17), proposta por Darnton, já que todos compartilhavam de um mesmo contexto histórico, apesar de não terem tido suas vidas registradas nos documentos.

\section{REFERÊNCIAS BIBLIOGRÁFICAS}

ANTONIL, André João. Cultura e opulência do Brasil. Belo Horizonte/São Paulo: Editora Itatialia/Edusp, 1982.

CERDAN, Marcelo A. O tempo que os escravos tinham para si: um estudo sobre autonomia escrava em Itu de 1850 a 1888. Tese, UNESP/Franca-SP, 2013.

DARNTON, Robert. O grande massacre de gato. E outros episódios da História Cultural francesa. 5a Edição. Rio de Janeiro: Editora Graal, 2006.

DEBRET, Jean Batiste. Viagem pitoresca e histórica ao Brasil. 2 volumes, São Paulo: Círculo do Livro, S/d.

GRAHAM, Maria. Diário de uma viagem ao Brasil. São Paulo: Editora Nacional, 1956.

KIDDER, Daniel P. Reminiscências de Viagens e permanências no Brasil (Província Sul). São Paulo: Martins Fontes/EDUSP, 1972.

KOSTER, Henry. Trabels in Brazil. $2^{\mathrm{a}}$ Edição. London: Çongman, Hurst, Rees, Orme and Brown, 1817.

NARDY FILHO, Francisco. A cidade de Ytu. Crônicas históricas. $2^{a}$ edição. Itu: Editora Ottoni, 6 volumes, 2000.

RUGENDAS, Johann Moritz. Viagem pitoresca através do Brasil. São Paulo: Círculo do Livro, s/d.

SAINT-HILAIRE, Auguste de. Segunda Viagem a Província de São Paulo. São Paulo: Livraria Martins, 1976.

WALSH, Robert. Notícias do Brasil. 2v. Belo Horizonte/São Paulo: Itatiaia/EDUSP, 1985. 